\title{
Rozpoznawanie ostrego niedokrwienia mózgu u pacjentów z zawrotami głowy
}

Diagnosis of acute cerebral ischaemia in patients with vertigo

\section{Kamil Kowalczyk, Dariusz Gąsecki}

Klinika Neurologii Dorosłych Gdańskiego Uniwersytetu Medycznego

\section{STRESZCZENIE}

Przypuszczalnie w Polsce każdego roku na oddziały ratunkowe i do izb przyjęć z powodu zawrotów głowy zgłasza się około 157 tys. pacjentów. Diagnostyka różnicowa tego schorzenia jest szeroka, przy czym groźne przyczyny dotyczą około 15\% przypadków, w tym u 2,2\% pacjentów jest to ostre niedokrwienie mózgu. Najnowsze podejście do diagnostyki zawrotów głowy polega na zastosowaniu algorytmu TiTrATE (ang. Timing, Triggers, And Targeted Examinations), który umożliwia wyróżnienie sześciu zespołów, z których cztery mają istotne znaczenie w kontekście ostrego niedokrwienia mózgu. Przyczyną prowokowanego epizodycznego zespołu przedsionkowego (napady zawrotów głowy wyzwalane przez określone czynności i zdarzenia) rzadko jest udar mózgu (zlokalizowany w tylnej jamie czaszki), częściej natomiast łagodne napadowe położeniowe zawroty głowy czy hipotonia ortostatyczna. Jedną z najczęstszych groźnych przyczyn spontanicznego epizodycznego zespołu przedsionkowego stanowi przemijający atak niedokrwienny. Prowokowany ostry zespół przedsionkowy może być spowodowany rozwarstwieniem tętnicy kręgowej. Wzorcową przyczyną spontanicznego ostrego zespołu przedsionkowego jest zapalenie nerwu przedsionkowego, którego różnicowanie z udarem mózgu stanowi duże wyzwanie, zwłaszcza dlatego, że badania obrazowe (nawet rezonans magnetyczny) są stosunkowo mało przydatne w ostrej fazie choroby. Najlepszym badaniem pozwalającym na odróżnienie tych dwóch schorzeń jest test HINTS (test pchnięcia głową - oczopląs - zbaczanie skośne gałek ocznych). O uszkodzeniu ośrodkowego układu nerwowego świadczy obecność co najmniej jednej z następujących cech: nieprawidłowy wynik testu pchnięcia głową, oczopląs zmiennokierunkowy/pionowy/krężny lub zbaczanie skośne gałek ocznych.

$$
\text { Choroby Serca i Naczyń 2019, } 16 \text { (3), 165-171 }
$$

Słowa kluczowe: zawroty głowy, udar niedokrwienny, przemijający atak niedokrwienny

\section{Adres do korespondencji:}

lek. Kamil Kowalczyk

Klinika Neurologii Dorosłych

Gdański Uniwersytet Medyczny

ul. Dębinki 7, 80-251 Gdańsk

e-mail:kkowalczyk@gumed.edu.pl 


\section{ABSTRACT}

In Poland, presumably about 157,000 patients every year present to emergency departments due to vertigo. The differential diagnosis of this condition is broad, with dangerous causes accounting for approximately $15 \%$ of cases, including acute cerebral ischaemia which accounts for $2.2 \%$. The present approach to the diagnosis of vertigo is based on the TITrATE algorithm (Timing, Triggers, And Targeted Examinations), which enables the identification of six syndromes, four of which are important in the context of acute cerebral ischaemia. Triggered episodic vestibular syndrome (incidents of vertigo provoked by specific activities and events) is rarely caused by stroke (in the posterior cranial fossa), and more often by benign paroxysmal positional vertigo or orthostatic hypotension. One of the most common dangerous causes of spontaneous episodic vestibular syndrome is a transient ischaemic attack. Post-exposure acute vestibular syndrome may be caused by vertebral artery dissection. The prototype cause of spontaneous acute vestibular syndrome is vestibular neuritis, and distinguishing it from stroke is a major challenge, especially given the relatively low usefulness of neuroimaging (even of magnetic resonance imaging) in the acute phase of the disease. The HINTS test (head impulse - nystagmus - test of skew) is the best method of distinguishing between these two conditions. The presence of at least one of the following features indicates damage to the central nervous system: abnormal head impulse test, directional changing/vertical/rotational nystagmus, or the presence of skew deviation.

Choroby Serca i Naczyń 2019, 16 (3), 165-171

Key words: vertigo, ischaemic stroke, transient ischaemic attack

\section{WPROWADZENIE}

Zawroty głowy stanowią przyczynę około 3,3\% wizyt na oddziałach ratunkowych wStanach Zjednoczonych [1]. Podobnych danych epidemiologicznych $w$ Polce nie zebrano, jednak przy uwzględnieniu, że w Polsce w 2017 roku na oddziałach ratunkowych i w izbach przyjęć udzielono pomocy niemal 4,8 mln osób [2], rocznie około 157 tys. pacjentów zgłasza się do tych placówek z powodu zawrotów głowy.

Pojęcie „zawroty głowy” obejmuje różne doznania, takie jak wirowanie, zaburzenia równowagi, dezorientacja, falowanie podłoża, kołysanie, omdlewanie i inne. Ich diagnostyka różnicowa jest szeroka, przy czym groźne przyczyny dotyczą około $15 \%$ przypadków, a ich częstość zwiększa się z wiekiem (poważne przyczyny występują $\mathrm{w}>25 \%$ przypadków zawrotów głowy u osób w wieku $>75$ lat) [1]. Udary mózgu i przemijające ataki niedokrwienne (TIA, transient ischaemic attacks) stanowią przyczynę około 2,2\% zawrotów głowy (odpowiednio 0,5\% i 1,7\%) [1]. Ogólnie rzecz biorąc, z jednej strony zawroty głowy to objaw niespecyficzny, który może występować zarówno w przebiegu udaru, jak i wielu innych stanów klinicznych, z drugiej strony w rzadkich przypadkach może to być jedyny objaw niedokrwienia ośrodkowego układu nerwowego. Z tych powodów w przypadku występowania zawrotów głowy ryzyko popełnienia błędu i przeoczenia prawidłowego rozpoznania jest duża [3, 4]. Biorąc pod uwagę powyższe czynniki oraz stosunkowo niską czułość tomografii komputerowej (CT, computed tomography), a nawet rezonansu magnetycznego (MR, magnetic resonance) w rozpoznawaniu udaru mózgu [3], niezwykle istotne jest takie postępowanie diagnostyczne, które pozwoli osiągnąć jak największą wykrywalność ostrego niedokrwienia mózgu u chorych $\mathrm{z}$ zawrotami. Bardzo ważnym zadaniem w diagnostyce zawrotów głowy jest odróżnienie przyczyn łagodnych od poważnych (zwłaszcza chorób układu sercowo-naczyniowego). W niniejszym artykule przedstawiono problematykę rozpoznawania udaru mózgu u pacjentów, których jedynym lub głównym objawem są zawroty głowy.

Ponieważ zdecydowana większość pacjentów zgłaszających się na oddziały ratunkowe lub do izb przyjęć z powodu zawrotów głowy nie choruje na udar mózgu, jego rozpoznanie pozostaje dużym wyzwaniem. Tomografia komputerowa jest mało czuła, a wykonywanie badania MR u wszystkich pacjentów z zawrotami jest 
zbyt kosztowne [3]. Poza tym w ostatnich latach podważa się tradycyjny podział zawrotów na układowe (schorzenia układu przedsionkowego), nieukładowe (przyczyny neurologiczne), stan przedomdleniowy (przyczyny sercowo-naczyniowe) oraz niespecyficzne (przyczyny psychiatryczne/metaboliczne), ponieważ na przykład osoby ze schorzeniami układu przedsionkowego podawały trzy rodzaje zawrotów, a zaledwie $25 \%$ z nich skarżyło się na zawroty typu układowego [3,5]. Nadmierne poleganie na takim podziale $\mathrm{w}$ diagnostyce różnicowej może zatem prowadzić do błędnego rozpoznania. Tym bardziej istotne jest korzystanie z narzędzi diagnostycznych, których skuteczność będzie największa.

\section{DEFINICJA ZAWROTÓW GLOWY}

Nieukładowe zawroty głowy (ang. dizziness) są definiowane jako uczucie zaburzonej lub ograniczonej orientacji przestrzennej bez fałszywego lub zniekształconego poczucia ruchu, natomiast zawroty głowy układowe (ang. vertigo) - jako uczucie ruchu własnego ciała, gdy taki ruch nie występuje, lub poczucie zniekształconego ruchu w przypadku prawidłowych ruchów głowy [6].

\section{POSTĘPOWANIE}

Najnowsze podejście do zawrotów głowy polega na zastosowaniu algorytmu TiTrATE (ang. Timing, Triggers, And Targeted Examinations). Termin „czas” (ang. timing) odnosi się do początku, czasu trwania oraz ewolucji zawrotów. "Czynniki wywołujące" (ang. triggers) to czynności, ruchy lub sytuacje, które powodują wystąpienie zawrotów u chorych z objawami występującymi okresowo. Czas oraz czynniki wywołujące pozwalają wyróżnić sześć zespołów: - prowokowany epizodyczny zespół przedsionkowy; - spontaniczny epizodyczny zespół przedsionkowy;

- prowokowany ostry zespół przedsionkowy;

- spontaniczny ostry zespół przedsionkowy;

- prowokowany przewlekły zespół przedsionkowy;

- spontaniczny przewlekły zespół przedsionkowy.

Następnie należy wykonać badania celowane, aby dokonać właściwego rozpoznania [7]. W niniejszym artykule omówiono tylko cztery pierwsze zespoły przedsionkowe, ponieważ nierozpoznanie ostrego niedokrwienia mózgu u chorych z tymi zespołami może mieć najpoważniejsze konsekwencje.

\section{EPIZODYCZNY ZESPÓŁ PRZEDSIONKOWY}

W epizodycznym zespole przedsionkowym objawy występują napadowo i trwają sekundy, minuty lub godziny (do tej kategorii nie należy zaliczać okresowo pojawiających się i ustępujących objawów trwających kilka tygodni, jak np. w stwardnieniu rozsianym). Pod uwagę należy wziąć czas utrzymywania się objawów $\mathrm{w}$ trakcie jednego epizodu, a nie całkowity czas trwania choroby. Wyróżnia się prowokowany oraz spontaniczny epizodyczny zespół przedsionkowy [7].

\section{Prowokowany epizodyczny zespół przedsionkowy}

Prowokowany epizodyczny zespół przedsionkowy to zespół wyzwalany określonymi czynnościami lub zdarzeniami (najczęściej zmianą pozycji z siedzącej na stojąca, odchyleniem głowy do tyłu, np. podczas mycia włosów, przekręcenie, się w łóżku; rzadziej manewrem Valsalvy lub głośnym dźwiękiem). Istotne jest odróżnienie czynników, które wyzwalają objawy od tych, które je nasilają (ruchy głową zazwyczaj nasilają zawroty pochodzenia przedsionkowego - łagodne i poważne, ośrodkowe i obwodowe, ostre i przewlekłe). Powszechnie uważa się, że nasilenie zawrotów przez ruchy głową jest typowe dla przyczyn obwodowych, jednak jest to przekonanie błędne. Głównym celem podczas badania pacjentów z prowokowanym epizodycznym zespołem przedsionkowym jest odtworzenie objawów. Najczęstsze przyczyny tego zespołu przedsionkowego to hipotensja ortostatyczna i łagodne napadowe położeniowe zawroty głowy (BPPV, benign paroxysmal positional vertigo). Niezwykle istotne jest odróżnienie chorób je naśladujących, czyli tak zwanych ośrodkowych napadowych położeniowych zawrotów głowy (CPPV, central paroxysmal positional vertigo), występujących na przykład w przypadku zmian w tylnej jamie czaszki, i poważnych przyczyn hipotensji ortostatycznej, takich jak krwawienie wewnętrzne [7].

\section{Napadowe położeniowe zawroty głowy}

Łagodne napadowe położeniowe zawroty głowy to najczęstsze zawroty głowy pochodzenia przedsionkowego [8], objawiające się napadami zawrotów głowy wyzwalanymi przez zmianę pozycji ciała i trwającymi kilkadziesiąt sekund [7,9]. Diagnostyka polega na wykonaniu specyficznych manewrów (m.in. test Dix-Hallpike'a, test Pagniniego-McClure'a) i wykazaniu odpowiedniego oczopląsu (zazwyczaj pionowo-obrotowego lub poziomego) [10, 11]. Łagodne napadowe położeniowe zawroty głowy są spowodowane przedostaniem się otolitów najczęściej z łagiewki do kanału półkolistego, natomiast CPPV, z którymi należy je różnicować, mogą być 
wywołane przez guzy lub udary zlokalizowane w tylnej jamie czaszki [7, 10, 12, 13]. Łagodne napadowe położeniowe zawroty głowy od CPPV można odróżnić na podstawie starannego badania gałek ocznych.

W przypadku CPPV oczopląs może być wywołany dowolnym położeniem głowy, a jego kierunek również może być dowolny, jednak najczęściej jest on pionowy $\mathrm{w}$ dół lub poziomy, natomiast w BPPV oczopląs najczęściej jest pionowo-obrotowy lub poziomy. W przebiegu patologii kanału półkolistego bocznego oczopląs może być dwufazowy i spontanicznie zmieniać kierunek nawet wtedy, gdy pozycja głowy się nie zmienia. Oczopląs w przebiegu CPPV może trwać5-60 s lub dłużej (w BPPV typowo trwa 5-90 s). W BPPV oczopląs występuje zazwyczaj po kilkusekundowym opóźnieniu (latencji), szybko osiąga maksymalne natężenie, a następnie ustaje, jeśli głowa jest utrzymywana w tej samej pozycji. Ośrodkowe położeniowe zawroty głowy mogą wystąpić od razu bądź z opóźnieniem, mogą (lecz nie muszą) zmieniać swój kierunek w czasie badania, a ich natężenie może się zmniejszać lub utrzymywać na tym samym poziomie [7].

\section{Spontaniczny epizodyczny zespół przedsionkowy}

Czas trwania zawrotów w przypadku spontanicznego epizodycznego zespołu przedsionkowego wynosi od kilku sekund do kilku dni (najczęściej od kilku minut do kilku godzin) [14], a jego częstość waha się od pojedynczego incydentu w miesiącu do wielu w ciągu dnia [7]. Ponieważ objawów nie można wywołać za pomocą prostego testu prowokacyjnego, a w chwili badania chorzy zazwyczaj nie wykazują objawów, to podstawą rozpoznania jest głównie wywiad chorobowy [7]. Do jednej z najczęstszych groźnych przyczyn spontanicznego epizodycznego zespołu przedsionkowego należy TIA. Dawniej uważano, że nie można podejrzewać TIA, gdy zawroty głowy są jedynym objawem [15], później jednak dowiedziono, że zawroty głowy mogą stanowić izolowany objaw TIA $[16,17]$. Zawroty stanowią najczęstszy objaw rozwarstwienia tętnicy kręgowej (typowo występującego u młodych pacjentów i którego najczęstszym powikłaniem jest udar niedokrwienny) [18] oraz zamknięcia tętnicy podstawnej [19]. Chorzy z TIA z tylnego zakresu unaczynienia są obciążeni wyższym ryzykiem udaru niedokrwiennego niż pacjenci z TIA z przedniego zakresu unaczynienia [20]. Wskaźnikiem TIA u pacjentów, u których wystąpił spontaniczny epizodyczny zespół przedsionkowy, jest obecność co najmniej 3 czynników ryzyka udaru mózgu (wiek > 55 lat, płeć męska, udar mózgu lub TIA w wywiadzie, choroba niedokrwienna serca, nadciśnienie tętnicze, cukrzyca, zaburzenia lipidowe, palenie tytoniu, stres emocjonalny, mniej niż $4 \mathrm{~h}$ aktywności fizycznej w tygodniu) [21] lub uzyskanie w skali $\mathrm{ABCD}^{2}$ (wiek $[\mathrm{Age}] \geq 60$ lat 1 pkt; ciśnienie tętnicze (Blood pressure) $\geq 140 / 90 \mathrm{~mm} \mathrm{Hg}$ 1 pkt; objawy kliniczne TIA(Clinical features): niedowład2 pkt., bez niedowładu -1 pkt; długość trwania objawów TIA (Duration) $>60$ min -2 pkt., $10-59$ min -1 pkt $<10$ min -0 pkt.; cukrzyca (Diabetes) obecna -1 pkt) więcej niż 3 punktów [22], choć przydatności tej skali nie potwierdzono w innych badaniach [23].

\section{OSTRY ZESPÓட PRZEDSIONKOWY}

Ostry zespół przedsionkowy występuje u 10-20\% pacjentów z zawrotami głowy [24] i obejmuje ciągłe zawroty głowy o nagłym początku, z nudnościami lub wymiotami, niestabilnością chodu, nietolerancją ruchów głowy oraz oczopląsem, trwające od kilku dni do kilku tygodni [25]. U większości pacjentów największe nasilenie objawów występuje na początku choroby, natomiast szybka poprawa - w pierwszym tygodniu, a stopniowe ustępowanie objawów - w ciągu kilku tygodni lub miesięcy. Ostry zespół przedsionkowy jest klasyfikowany jako prowokowany lub spontaniczny [7].

\section{Prowokowany ostry zespół przedsionkowy}

Prowokowany ostry zespół przedsionkowy może być wywołany przez uraz głowy, zatrucie lekami, stosowanie nielegalnych substancji psychoaktywnych lub zatrucie tlenkiem węgla [7]. Szczególną uwagę należy zwrócić na urazowe rozwarstwienie tętnicy kręgowej.

\section{Spontaniczny ostry zespół przedsionkowy}

Niezwykle ważne jest odróżnienie spontanicznego ostrego zespołu przedsionkowego od prowokowanego epizodycznego zespołu przedsionkowego. W spontanicznym ostrym zespole przedsionkowym u pacjenta występują zawroty głowy $\mathbf{w}$ spoczynku, które nasilają się w czasie dowolnych ruchów głową, natomiast pacjenci z prowokowanym epizodycznym zespołem przedsionkowym nie przejawiają objawów w spoczynku, a zawroty pojawiają się podczas określonych ruchów głową. Oznacza to, że nie można wykonywać testów pozycyjnych (np. manewru Dix-Hallpike'a) u pacjentów z ostrym zespołem przedsionkowym [7]. Wzorcowym przykładem spontanicznego ostrego zespołu przedsionkowego jest zapalenie nerwu przed- 
sionkowego, które należy różnicować z niedokrwieniem obejmującym boczną część mostu, móżdżek lub ucho wewnętrzne [24], rzadziej - z krwotokiem do móżdżku [26]. Diagnostykę różnicową udaru mózgu i obwodowych zaburzeń przedsionkowych utrudnia fakt, że u mniej niż $1 / 5$ chorych ze spontanicznym ostrym zespołem przedsionkowym występują wyraźne objawy neurologiczne [7]. Badaniami często wykonywanymi w celu odróżnienia centralnego od obwodowego spontanicznego ostrego zespołu przedsionkowego są badania neuroobrazowe. W badaniu retrospektywnym czułość badania CT głowy w wykrywaniu udarów niedokrwiennych mózgu w obrębie tylnej jamy czaszki wynosi nawet $42 \%$ [27], jednak w badaniu prospektywnym czułość tej samej techniki w wykrywaniu przyczyny zawrotów głowy pochodzenia ośrodkowego sięga zaledwie 7\% [28], badanie to jest zatem nieprzydatne w wykrywaniu udarów niedokrwiennych u chorych ze spontanicznym ostrym zespołem przedsionkowym [7]. Również badanie MR głowy nie pozwala na wykrycie udaru niedokrwiennego mózgu w tylnej jamie czaszki u $20 \%$ chorych w pierwszych $24-48$ godzinach od wystąpienia objawów [24,29]. W przypadku małych udarów niedokrwiennych ( $\leq 10 \mathrm{~mm}$ średnicy) czułość badania MR w wykrywaniu udaru niedokrwiennego u pacjentów z zawrotami jest jeszcze mniejsza i wynosi około 50\% [30]. Powszechną praktyką pozostaje wykonywanie badania obrazowego u starszych pacjentów obarczonych naczyniowymi czynnikami ryzyka, lecz takie podejście wiąże się z niebezpieczeństwem nierozpoznania udaru mózgu u młodego chorego nieobarczonego żadnymi czynnikami ryzyka chorób układu sercowo-naczyniowego [7]. Od 10\% do $20 \%$ pacjentów z ostrym zespołem przedsionkowym bez żadnych czynników ryzyka doznaje udaru mózgu [24]. Młody wiek, brak klasycznych czynników ryzyka chorób układu sercowo-naczyniowego, prawidłowe wyniki badania neurologicznego i CT głowy przyczyniają się do tego, że u pacjentów z izolowanymi zawrotami głowy rozpoznanie udaru mózgu zbyt rzadko jest brane pod uwage [7]. Narzędziem, które u pacjentów ze spontanicznym ostrym zespołem przedsionkowym w sposób najpewniejszy pozwala na odróżnienie udaru mózgu od schorzenia obwodowego, jest test HINTS (ang. head impulse - nystagmus - test of skew; test pchnięcie głową - oczopląs - zbaczanie skośne gałek ocznych). Warto dodać, że dokładność tego testu jest większa niż badania MR głowy wykonanego w ostrej fazie choroby [25].
Jednym z badań w teście HINTS jest ocena oczopląsu. W przypadku zespołu obwodowego oczopląs powinien być jednokierunkowy oraz nasilać się przy patrzeniu w stronę fazy szybkiej, natomiast dla zespołu ośrodkowego charakterystyczny jest oczopląs krężny, pionowy lub zmiennokierunkowy (choć niekiedy oczopląs może mieć charakter poziomy i naśladować przyczynę obwodową, co może być wywołane uszkodzeniem w zakresie unaczynienia tętnicy przedniej dolnej móżdżku — patrz wyżej) [25].

Najlepszym pojedynczym testem pozwalającym odróżnić udar mózgu od zapalenia nerwu przedsionkowego u chorych ze spontanicznym zespołem przedsionkowym jest test pchnięcia głową [31]. Badanie to, służące ocenie odruchu przedsionkowo-ocznego, można wykonać przy łóżku chorego. Pacjent siedzi naprzeciwko osoby badającej i ma za zadanie utrzymywać spojrzenie na nosie badającego. Z kolei badający trzyma głowę pacjenta $\mathrm{w}$ linii pośrodkowej i następnie gwałtownym ruchem obraca ją o około 20 stopni w jedną, a potem w drugą stronę. Możliwość utrzymania wzroku na nosie badającego przez cały czas oznacza prawidłowy wynik testu (nienaruszony odruch przedsionkowo-oczny), co wskazuje na centralną przyczynę ostrego zespołu przedsionkowego. Wynik testu jest nieprawidłowy (dodatni), gdy początkowo gałki oczne podążają za ruchem głowy, a następnie przemieszczają się w przeciwnym kierunku na nos badającego (sakkada korekcyjna) ma to miejsce w przypadku uszkodzeń obwodowych (np. zapalenia nerwu przedsionkowego) [31]. Należy pamiętać, że niekiedy wynik tego testu może być dodatni w udarach obejmujących boczną część mostu, co może być spowodowane między innymi zajęciem jąder przedsionkowych lub niedokrwieniem początkowego odcinka nerwu przedsionkowego [32]. Taka sytuacja może wystąpić w przypadku udaru niedokrwiennego z obszaru unaczynienia tętnicy przedniej dolnej móżdżku, który obejmuje boczną część mostu wraz z jądrami przedsionkowymi, a więc struktur wchodzących $\mathrm{w}$ skład obwodowej części narządu przedsionkowego [33].

Trzeci element testu to ocena zbaczania skośnego gałek ocznych [25]. Jest to niewspółosiowe ustawienie gałek ocznych w pionie spowodowane asymetrią impulsów nerwowych płynących $\mathrm{z}$ układu przedsionkowego (zwłaszcza otolitów) do układu odpowiedzialnego za ruchomość gałek ocznych [34]. Zbaczanie skośne gałek ocznych najłatwiej wykazać, wykonując test naprzemiennego zasłaniania oczu. Podczas tego badania 
Tabela 1. Naczyniowo-mózgowe przyczyny zespołu przedsionkowego (na podstawie [3])

\begin{tabular}{|c|c|c|}
\hline Zespół & TIA & Udar niedokrwienny \\
\hline $\begin{array}{l}\text { Prowokowany epizodyczny zespół przed- } \\
\text { sionkowy (krótkie, powtarzające się objawy) }\end{array}$ & Zespół obrotowego ucisku tętnicy kręgowej & $\begin{array}{l}\text { CPPV spowodowane niewielkim udarem } \\
\text { niedokrwiennym w pobliżu komory IV }\end{array}$ \\
\hline $\begin{array}{l}\text { Spontaniczny epizodyczny zespół przed- } \\
\text { sionkowy }(<24 \mathrm{~h})\end{array}$ & $\begin{array}{l}\text { Izolowane zawroty glowy związane z pato- } \\
\text { logią PICA; zawroty glowy związane z pato- } \\
\text { logią AICA } \pm \text { szumy uszne lub niedosłuch }\end{array}$ & $\begin{array}{l}\text { Niewielki udar niedokrwienny powodujący } \\
\text { przemijające objawy }\end{array}$ \\
\hline $\begin{array}{l}\text { Prowokowany ostry zespół przedsionkowy } \\
\text { (> } 24 \text { h) }\end{array}$ & $\begin{array}{l}\text { Uraz powodujący rozwarstwienie tętnicy } \\
\text { kręgowej/TIA }\end{array}$ & $\begin{array}{l}\text { Uraz powodujący rozwarstwienie tętnicy } \\
\text { kręgowej/udar }\end{array}$ \\
\hline $\begin{array}{l}\text { Spontaniczny ostry zespół przedsionkowy } \\
\text { (> } 24 \text { h) }\end{array}$ & $\begin{array}{l}\text { Brak doniesień (trudność w odróżnieniu } \\
\text { tego zespołu od migreny przedsionkowej) }\end{array}$ & $\begin{array}{l}\text { Izolowane zawroty głowy związane z pato- } \\
\text { logią PICA; zawroty głowy związane z pato- } \\
\text { logią AICA } \pm \text { szumy uszne lub niedosłuch }\end{array}$ \\
\hline
\end{tabular}

TIA (transient ischaemic attack) — przemijający atak niedokrwienny; CPPV (central paroxysmal positional vertigo) — ośrodkowe napadowe położeniowe zawroty głowy; PICA (posterior inferior cerebellar artery) — tętnica tylna dolna móżdżku; AICA (anterior inferior cerebellar artery) — tętnica przednia dolna móżdżku

pacjent patrzy na badającego, a badający kartką lub ręką zakrywa jedno oko chorego. Następnie szybko odsłania to oko i zasłania drugie. Później należy ponownie zasłonić pierwsze oko. Pojawienie się pionowego ruchu gałek ocznych wskazuje na ich zbaczanie skośne [35].

Obecność co najmniej jednej nieprawidłowości wskazującej na uszkodzenie ośrodkowe (prawidłowy test pchnięcia głową, oczopląs zmiennokierunkowy/ /pionowy/krężny oraz zbaczanie skośne gałek ocznych) wskazuje na udar mózgu. Test HINTS wykazuje większą czułość (100\% vs. $72 \%$ ) niż badanie MR głowy z sekwencją DWI (ang. diffusion-weighted imaging), czyli obrazowanie zależne od dyfuzji, wykonane w pierwszych 24 -48 godzinach od początku choroby i porównywalną specyficzność (96\% vs. 100\%) w odróżnianiu udaru mózgu od obwodowej patologii u chorych z ostrym zespolem przedsionkowym [25].

W tabeli 1 przedstawiono możliwe naczyniowo-mózgowe przyczyny zespołu przedsionkowego [3].

\section{PODSUMOWANIE}

Nierozpoznanie ostrego niedokrwienia mózgu jest groźne dla pacjenta, ponieważ może sprawić, że nie zostanie zastosowane odpowiednie leczenie, takie jak tromboliza [36], wczesna profilaktyka wtórna [3], leczenie operacyjne powikłań, na przykład złośliwego obrzęku mózgu [37], bądź trombektomia mechaniczna. Trudności w rozpoznaniu tego schorzenia są duże zwłaszcza w przypadku pacjentów z izolowanymi lub dominującymi zawrotami głowy. Podsumowując, ostre niedokrwienie mózgu u pacjentów z zawrotami głowy należy szczególnie podejrzewać w następujących przypadkach:

- obecności innych wyraźnych objawów neurologicznych, wskazujących na niedokrwienie w obrębie tylnej jamy czaszki (takich jak dyzartria, dysfagia, ataksja, zespół Hornera, zaburzenia czucia);

- zawrotów głowy związanych ze zmianą pozycji głowy z objawami nietypowymi dla łagodnych położeniowych zawrotów głowy lub nieustępującymi po odpowiednim leczeniu;

- spontanicznego epizodycznego zespołu przedsionkowego u chorych obciążonych co najmniej 3 czynnikami ryzyka chorób układu sercowo-naczyniowego lub pacjentów, którzy w skali $\mathrm{ABCD}^{2}$ uzyskali wynik przekraczający 3 punkty;

- nieprawidłowego wyniku testu HINTS u chorych ze spontanicznym ostrym zespołem przedsionkowym. W niektórych przypadkach udar mózgu można potwierdzić, wykonując badanie neuroobrazowe (MR) po kilku dniach od wystąpienia objawów.

\section{KONFLIKT INTERESÓW}

Autorzy nie zgłaszają konfliktu interesów.

\section{Piśmiennictwo}

1. Newman-Toker DE, Hsieh YH, Camargo CA, et al. Spectrum of dizziness visits to US emergency departments: cross-sectional analysis from a nationally representative sample. Mayo Clin Proc. 2008; 83(7): 765-775, doi: 10.4065/83.7.765, indexed in Pubmed: 18613993.

2. Pomoc doraźna i ratownictwo medyczne w 2017 r. https://stat.gov.pl/ /download/gfx/portalinformacyjny/pl/defaultaktualnosci/5513/14/2/1/pomoc dorazna i ratownictwo medyczne_w_2017 r.pdf(03.02.2019).

3. Saber Tehrani AS, Kattah JC, Kerber KA, et al. Diagnosing Stroke in Acute Dizziness and Vertigo: Pitfalls and Pearls. Stroke. 2018; 49(3): 788-795, doi: 10.1161/STROKEAHA.117.016979, indexed in Pubmed: 29459396.

4. Newman-Toker DE, Moy E, Valente E, et al. Missed diagnosis of stroke in the emergency department: a cross-sectional analysis of a large population-based sample. Diagnosis (Berl). 2014; 1(2): 155-166, doi: 10.1515/dx-2013-0038, indexed in Pubmed: 28344918.

5. Kerber KA, Callaghan BC, Telian SA, et al. Dizziness Symptom Type Prevalence and Overlap: A US Nationally Representative Survey. 
Am J Med. 2017; 130(12): 1465.e1-1465.e9, doi: 10.1016/j.amjmed.2017.05.048, indexed in Pubmed: 28739195.

6. Bisdorff A, Von Brevern M, Lempert T, et al. Classification of vestibular symptoms: towards an international classification of vestibular disorders. J Vestib Res. 2009; 19(1-2): 1-13, doi: 10.3233/VES-2009-0343, indexed in Pubmed: 19893191.

7. Newman-Toker DE, Edlow JA. TiTrATE: ANovel, Evidence-Based Approach to Diagnosing Acute Dizziness and Vertigo. Neurol Clin. 2015; 33(3): $577-$ -599, viii, doi: 10.1016/j.ncl.2015.04.011, indexed in Pubmed: 26231273.

8. von Brevern M, Radtke A, Lezius F, et al. Epidemiology of benign paroxysmal positional vertigo: a population based study. J Neurol Neurosurg Psychiatry. 2007; 78(7): 710-715, doi: 10.1136/ /jnnp.2006.100420, indexed in Pubmed: 17135456.

9. Parnes LS, Agrawal SK, Atlas J. Diagnosis and management of benign paroxysmal positional vertigo (BPPV). Can Med Assoc J. 2003; 169: 681-93.

10. Fife TD, Iverson DJ, Lempert T, et al. Quality Standards Subcommittee American Academy of Neurology. Practice parameter: therapies for benign paroxysmal positional vertigo (an evidence-based review): report of the Quality Standards Subcommittee of the American Academy of Neurology. Neurology. 2008; 70(22): 2067-2074, doi: 10.1212/01. wnl.0000313378.77444.ac, indexed in Pubmed: 18505980.

11. von Brevern M, Bertholon P, Brandt $T$, et al. Benign paroxysmal positional vertigo: Diagnostic criteria. J Vestib Res. 2015; 25(3-4): 105-117, doi: 10.3233/VES-150553, indexed in Pubmed: 26756126

12. Johkura K. Central paroxysmal positional vertigo: isolated dizziness caused by small cerebellar hemorrhage. Stroke. 2007; 38(6): e26-e27; author reply e28, doi: 10.1161/STROKEAHA.106.480319, indexed in Pubmed: 17446419

13. Dunniway HM, Welling DB. Intracranial tumors mimicking benign paroxysmal positional vertigo. Otolaryngol Head Neck Surg. 1998; 118(4): 429_ -436, doi: 10.1177/019459989811800401, indexed in Pubmed: 9560091.

14. Lempert T. Recurrent Spontaneous Attacks of Dizziness. Contin Lifelong Learn Neurol. 2012; 18: 1086-1101, doi: 10.1212/01. con.0000421620.10783.ac

15. A Classification and Outline of Cerebrovascular Diseases II. Stroke. 1975; 6(5): 564-616, doi: 10.1161/01.str.6.5.564.

16. Hoshino T, Nagao T, Mizuno S, et al. Transient neurological attack before vertebrobasilar stroke. J Neurol Sci. 2013; 325(1-2): 39-42, doi: 10.1016/j.jns.2012.11.012, indexed in Pubmed: 23235138.

17. Paul NLM, Simoni M, Rothwell PM, et al. Oxford Vascular Study. Transient isolated brainstem symptoms preceding posterior circulation stroke: a population-based study. Lancet Neurol. 2013; 12(1): 65-71, doi: 10.1016/S1474-4422(12)70299-5, indexed in Pubmed: 23206553.

18. Gottesman RF, Sharma P, Robinson KA, et al. Clinical characteristics of symptomatic vertebral artery dissection: a systematic review. Neurologist. 2012; 18(5): 245-254, doi: 10.1097/NRL.0b013e31826754e1, indexed in Pubmed: 22931728.

19. von Campe G, Regli F, Bogousslavsky J. Heralding manifestations of basilar artery occlusion with lethal or severe stroke. J Neurol Neurosurg Psychiatry. 2003; 74(12): 1621-1626, doi: 10.1136/jnnp.74.12.1621, indexed in Pubmed: 14638878.

20. Flossmann E, Rothwell PM. Prognosis of vertebrobasilar transient ischaemic attack and minor stroke. Brain. 2003; 126(Pt 9): 1940-1954, doi: 10.1093/brain/awg197, indexed in Pubmed: 12847074.

21. Moubayed SP, Saliba I. Vertebrobasilar insufficiency presenting as isolated positional vertigo or dizziness: a double-blind retrospective cohort study. Laryngoscope. 2009; 119(10): 2071-2076, doi: 10.1002/ /lary.20597, indexed in Pubmed: 19688845

22. Navi BB, Kamel H, Shah MP, et al. Application of the ABCD2 score to identify cerebrovascular causes of dizziness in the emergency department. Stroke. 2012; 43(6): 1484-1489, doi: 10.1161/STROKEAHA.111.646414, indexed in Pubmed: 22442167.

23. Amarenco P, Labreuche J, Lavallée PC. Patients with transient ischemic attack with ABCD2 <4 can have similar 90-day stroke risk as patients with transient ischemic attack with $A B C D 2 \geq 4$. Stroke. 2012; 43(3): 863-865, doi: 10.1161/STROKEAHA.111.636506, indexed in Pubmed: 22156685.

24. Tarnutzer AA, Berkowitz AL, Robinson KA, et al. Does my dizzy patient have a stroke? A systematic review of bedside diagnosis in acute vestibular syndrome. CMAJ. 2011; 183(9): E571-E592, doi: 10.1503/ /cmaj.100174, indexed in Pubmed: 21576300.

25. Kattah JC, Talkad AV, Wang DZ, et al. HINTS to diagnose stroke in the acute vestibular syndrome: three-step bedside oculomotor examination more sensitive than early MRI diffusion-weighted imaging. Stroke. 2009; 40(11): 3504-3510, doi: 10.1161/STROKEAHA.109.551234, indexed in Pubmed: 19762709.

26. Kerber KA, Burke JF, Brown DL, et al. Does intracerebral haemorrhage mimic benign dizziness presentations? A population based study. Emerg Med J. 2012; 29(1): 43-46, doi: 10.1136/emj.2010.104844, indexed in Pubmed: 21245473.

27. Hwang DY, Silva GS, Furie KL, et al. Comparative sensitivity of computed tomography vs. magnetic resonance imaging for detecting acute posterior fossa infarct. J Emerg Med. 2012; 42(5): 559-565, doi: 10.1016/j.jemermed.2011.05.101, indexed in Pubmed: 22305149.

28. Ozono Y, Kitahara T, Fukushima M, et al. Differential diagnosis of vertigo and dizziness in the emergency department. Acta Otolaryngol. 2014; 134(2): 140-145, doi: 10.3109/00016489.2013.832377, indexed in Pubmed: 24308666.

29. Newman-Toker DE, Kerber KA, Hsieh YH, et al. HINTS outperforms $A B C D 2$ to screen for stroke in acute continuous vertigo and dizziness. Acad Emerg Med. 2013; 20(10): 986-996, doi: 10.1111/acem.12223, indexed in Pubmed: 24127701.

30. Saber Tehrani AS, Kattah JC, Mantokoudis G, et al. Small strokes causing severe vertigo: frequency of false-negative MRIs and nonlacunar mechanisms. Neurology. 2014; 83(2): 169-173, doi: 10.1212/ /WNL.0000000000000573, indexed in Pubmed: 24920847.

31. Edlow JA, Newman-Toker DE, Savitz SI. Diagnosis and initial management of cerebellar infarction. Lancet Neurol. 2008; 7(10): 951-964, doi: 10.1016/S1474-4422(08)70216-3, indexed in Pubmed: 18848314.

32. Newman-Toker DE, Kattah JC, Alvernia JE, et al. Normal head impulse test differentiates acute cerebellar strokes from vestibular neuritis. Neurology. 2008; 70(24 Pt 2): 2378-2385, doi: 10.1212/01. wnl.0000314685.01433.0d, indexed in Pubmed: 18541870.

33. Kim JS, Calan LR. Vertebrobasilar Disease. In: Grotta J, Albers G, Broderick J, et al. ed. Stroke Pathophysiology, Diagnosis, and Management. 6th Edition. Elsevier Inc. 2016: 413-448.

34. Brodsky MC, Donahue SP, Vaphiades M, et al. Skew deviation revisited. Surv Ophthalmol. 2006; 51(2): 105-128, doi: 10.1016/j.survophthal.2005.12.008, indexed in Pubmed: 16500212.

35. Fuller G. Badanie neurologiczne. To proste. IV. Elsevier Urban \& Partner, Wrocław 2008.

36. Kuruvilla A, Bhattacharya P, Rajamani K, et al. Factors associated with misdiagnosis of acute stroke in young adults. J Stroke Cerebrovasc Dis. 2011; 20(6): 523-527, doi: 10.1016/j.jstrokecerebrovasdis.2010.03.005, indexed in Pubmed: 20719534.

37. Wijdicks EFM, Sheth KN, Carter BS, et al. American Heart Association Stroke Council. Recommendations for the management of cerebral and cerebellar infarction with swelling: a statement for healthcare professionals from the American Heart Association/American Stroke Association. Stroke. 2014; 45(4): 1222-1238, doi: 10.1161/01. str.0000441965.15164.d6, indexed in Pubmed: 24481970. 